\title{
IMPACT OF CHANGES IN CLIMATE AND LAND USE ON THE FUTURE STREAMFLOW FLUCTUATION: CASE STUDY MERANGIN TEMBESI WATERSHED, JAMBI PROVINCE, INDONESIA
}

\author{
Suria Tarigan ${ }^{\mathrm{a}}$, Akhmad Faqih ${ }^{\mathrm{b}}$ \\ ${ }^{a}$ Department of Soil Sciences and Natural Resource Management, Bogor Agricultural University, Indonesia, \\ Kampus IPB Darmaga, Bogor 16680 - suriatarigan2014@ gmail.com \\ ${ }^{b}$ Department of Geophysics and Meteorology, Faculty of Mathematics and Natural Sciences, Bogor Agricultural \\ University, Indonesia, Kampus IPB Darmaga, Bogor 16680
}

\begin{abstract}
Beside land use change, future climate change potentially alters streamflow fluctuation of a river basin in Indonesia. We investigated relative impact of changes in climate and land use on the streamflow fluctuation of a watershed in Jambi Province, Indonesia for future condition (2025). To account for the climate change, we simulated future rainfall and temperature scenarios using the downscaled rainfall and mean surface temperature of 24 CMIP5 GCM outputs with moderate scenario of RCP4.5. We used distributed hydrologic model (SWAT) to simulate relative impact of changes in climate and land use on the future streamflow fluctuation. The SWAT model performed well with the Nash-Sutcliff efficiency values of 0.80-0.85 (calibration) and 0.84-0.86 (validation). The results indicated that the climate change caused $32 \%$ decrease of the minimum discharge during dry season and $96 \%$ increase of the maximum peak discharge during rainy season. Meanwhile, the land use change led to $40 \%$ decrease of the minimum discharge in the dry season and 65\% increase of the maximum peak discharge in wet season. Both changes indicated significant impact on the extreme events such as discharge and minimum discharge. The impact of the climate change on the increased peak discharge is more significant compared to that of the land use change. Meanwhile, the impact of the land use change on the minimum discharge is more significant compared to that of the climate change. The results of this study pointed out that both climate and land use changes potentially become crucial factors for the future discharge fluctuation in Indonesia.
\end{abstract}

Keywords: Cimate change, land use change, streamflow fluctuation, SWAT model

(Diterima: 08-06-2018; Disetujui: 10-10-2018)

\section{Introduction}

Categorized as a humid tropical country, Indonesia has abundant water resources. According to Pereira et al. (2002), water is becoming scarce not only in drought prone regions but also in areas where rainfall is abundant. Annual quantity of available water exceeds demands in most regions in Indonesia. Nevertheless, water scarcity phenomenon in Indonesia occurs in almost all regions during dry season. Seasonal variability of streamflow is very high in most part of Indonesia causing unsecure water availability for agricultural activities. Predicted climate and land use changes are considered as the main drivers for future increased of rainfall and streamflow fluctuation (Boer and Faqih, 2004; Nayor et al., 2007; Junaidi and Tarigan, 2011; Tarigan et al., 2016; Tarigan, 2016a; Tarigan, 2016b). Therefore, water availability crisis driven by streamflow fluctuation can be a major constraint for agriculture development in coming decades and particularly in Asia and this will require major mitigation and adaptation strategies (Rijsberman, 2006). Aim of this study was to investigate relative impact of change in climates and land use change on the streamflow fluctuation of a watershed.

Impact of changes in climate and land use in streamflow fluctuation requires different mitigation and adaptation options. The ability to separate relative contribution of both factors enables us to set up priority on the appropriate mitigation or adaptation options (Tarigan et al., 2015; Tarigan et al., 2016a; Tarigan, 2016b; Tarigan, 2018). Impact due to the climate change is difficult to mitigate and therefore adaptation strategies are more appropriate. On the other hand, impact due to the land use changes especially those related to the plantation expansion can be mitigated by implementing good agricultural practices (Satriawan et al., 2017).

In Indonesia, the oil palm area increased from 0.7 million ha in 1990 to 11 million ha in 2015 (Ditjenbun, 2015; Tarigan et al., 2016). Additional land demand for palm oil production is expected to increase continuously in Indonesia in 2020-2050 (Wicke et al., 2011; Afriyanti et al., 2016). While plantation has improved farmer and regional economic, it has been subject to the environmental concerns (Klasen et al., 2016). The land use change alters local water cycle including increased transpiration (Roell et al., 2015; Hardanto et al., 2017), increased evapotranspiration (Babel et al., 2011; Meijide et al., 2017), decreased infiltration (Banabas et al., 2008; Tarigan et al., 2016), reduced minimum discharge (Adnan and Atkinson, 2011; Comte et al., 2012; Merten et al., 2016) and water quality (Sinukaban et al., 2000; Babel et al., 2011). All these changes potentially increase streamflow fluctuation in a river basin.

Besides the land use change, climate change is also considered as a potential factor for water cycle and streamflow fluctuation. The climate change alters temperature and the precipitation pattern. The higher the 
temperature, the higher the evapotranspiration and the lower the annual streamflow volume are. According to Babel et al. (2014), Tmax is predicted to increase by 2.1 ${ }^{\circ} \mathrm{C}$ under A2 scenario and by $1.5^{\circ} \mathrm{C}$ under B2 scenario in Bagmati River Basin, Nepal in 2080. Higher evapotranspiration intensified water deficits in dry season (Mcintyre, 2007). According to the Naylor et al., (2007), seasonal pattern of rainfall in Indonesia has changed with up to $75 \%$ decrease in rainfall in the dry season (July-September). Meanwhile, Hulme and Sheard (1999), predcited that during the wet season (December-February), parts of Sumatra and Kalimantan become 10 to 30 percent wetter by the 2080's. In contrast, rainfall pattern during the dry season (June-August) are becoming drier. Several methods can be used to investigate relative impacts of land use and climate change on streamflow fluctuation. The approaches can be classified as empirically-based and process-based. Empirical-based approaches use long-term historical data to analyze the changes ( $\mathrm{Li}$ et al., 2004; Ma et al., 2008; Zhang et al., 2008; Bao et al., 2012; Mwangi et al., 2016). Process-based method implements physically- based hydrological models. The change impact is determined by varying climate and crop inputs and landuse settings (Khoi et al., 2014; Guo et al., 2016; Zhang et al., 2016). Process-based approach require more data as input and subject to high uncertainty in parameter estimation (Zhang et al., 2016; Xu et al., 2014). In this study we used semi process-based and distributed hydrologic model (SWAT) to analyze relative impact of changes in climate and land use on the streamflow fluctuations.

\section{Materials and Methods}

\subsection{Study Site}

The study site is located in Merangin Tembesi watershed, Jambi Province of Sumatra, Indonesia (Fig. 1). The Merangin Tembesi watershed area is approximately $1,345,500$ ha and is experiencing rapid land use change, (Drescher et al., 2016).

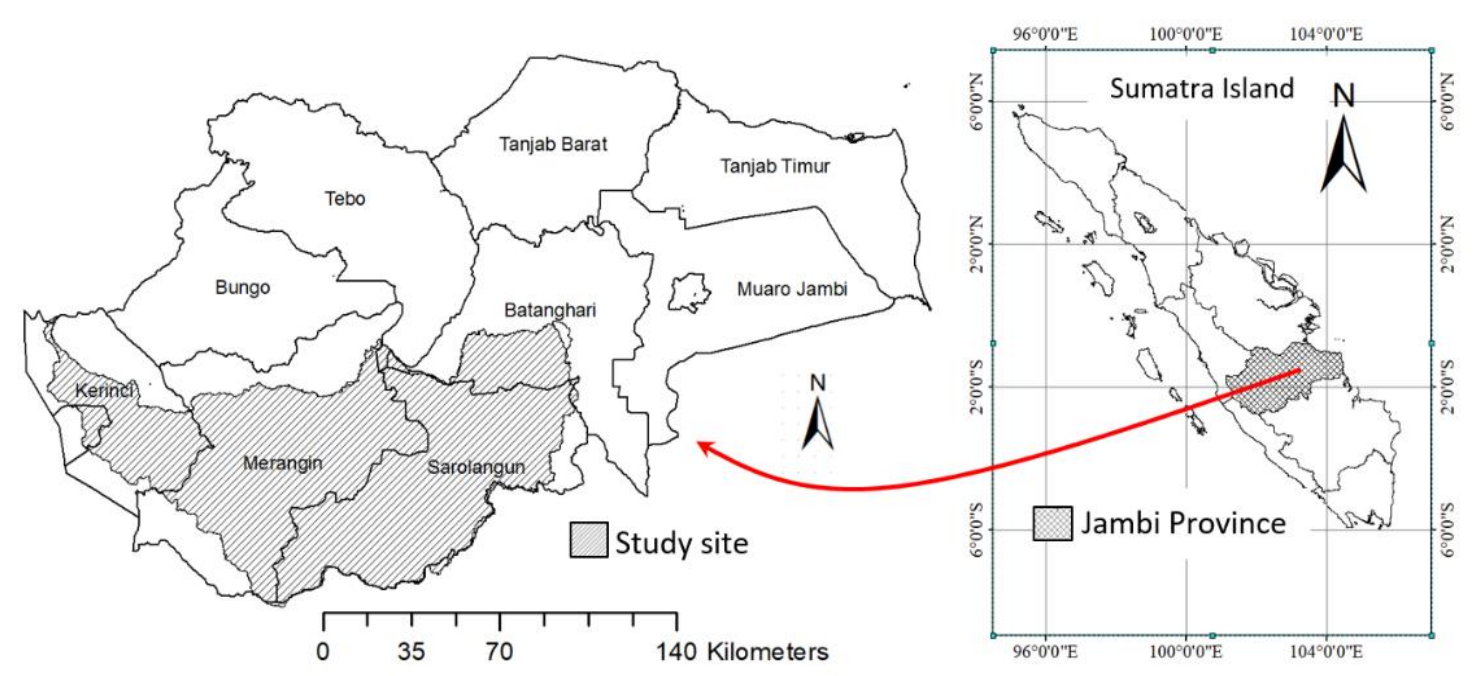

Figure 1. Study site in Jambi Province of Sumatra, Indonesia

\subsection{Data Collection}

We used semi process-based hydrological model (SWAT) to quantify the water balance of a watershed on a daily basis, climate change simulation and other water resource infrastructure (Arnold et al., 2012; Zuma et al., 2017). Input data for the SWAT model include soils, land use, temperature, humidity, radiation, and streamflow data (Table 1). Besides soil type boundary derived from soil map, we also carried out field data collection including hydraulic conductivity (SOL_K), bulk density (SOL_BD), available water content (SOL_AWC) and texture for the SWAT model input.

\subsection{Land Use Change}

Predicted land use changes in Merangin Tembesi watershed for year 2025 was based on the future concession permit of plantation crops obtained from various sources including Agricultural Plantation offices (Ditjenbun, 2015) and unpublished map from WARSI. The land use change alters water cycle characteristic such as infiltration, interception, and surface run off (Tarigan et al., 2016). These changes were reflected in the SWAT model input by adjusting relevant parameters such as $\mathrm{CN}$ (curve number), OV_N (Manning's "n" value for overland flow), SOL_K (saturated hydraulic conductivity $\left(\mathrm{mm} \mathrm{h}^{-1}\right)$ and SOL_AWC (available water capacity of the soil $\left(\mathrm{mm} \mathrm{H}_{2} \mathrm{O} \mathrm{mm} \mathrm{mm}^{-1}\right.$ soil) using field data and references as suggested in SWAT manual book.

Table 1. Sources of the model layer data, rainfall, climate and 
discharge data

\begin{tabular}{|c|c|c|}
\hline Data type & Source Data & Resolution \\
\hline Slope characteristics & $\begin{array}{l}\text { DEM from SRTM } \\
\text { (srtm.csi.cgiar.org) }\end{array}$ & $90 \mathrm{~m}$ \\
\hline Soil types & $\begin{array}{l}\text { Soil map from the } \\
\text { Soil Research Insti- } \\
\text { tute, Bogor }\end{array}$ & $1: 250,000$ \\
\hline Land use change & $\begin{array}{l}\text { Land use map from } \\
\text { the Regional Plan- } \\
\text { ning office } \\
\text { (BAPPEDA) and }\end{array}$ & $1: 100,000$ \\
\hline $\begin{array}{l}\text { Rainfall data from } \\
\text { Rantau Pandan, Siulak } \\
\text { Deras, Muara Imat sta- } \\
\text { tions and climate data } \\
\text { from Jambi, Pematang } \\
\text { Kabau and Bungku } \\
\text { stations. }\end{array}$ & $\begin{array}{l}\text { BMKG office (Mete- } \\
\text { orology, Climatology } \\
\text { and Geophysics } \\
\text { Agency) and } \\
\text { CRC990 (Collabora- } \\
\text { tive Research Centre } \\
990)\end{array}$ & Daily data \\
\hline $\begin{array}{l}\text { Streamflow discharge } \\
\text { from Muara Tembesi } \\
\text { hydrological station }\end{array}$ & $\begin{array}{l}\text { Ministry of Public } \\
\text { Works (BBWS) }\end{array}$ & Daily data \\
\hline
\end{tabular}

Table 2. Land use change from 2010 (baseline) to 2025

\begin{tabular}{lrrrrr}
\hline \multirow{2}{*}{ Land use types } & \multicolumn{2}{c}{$\mathbf{2 0 1 0}$ (baseline) } & \multicolumn{2}{c}{$\mathbf{2 0 2 5}$ (predicted) } & Change \\
\cline { 2 - 6 } & \multicolumn{1}{c}{ ha } & $\mathbf{( \% )}$ & \multicolumn{1}{c}{ ha } & \multicolumn{1}{c}{$\mathbf{( \% )}$} & \multicolumn{1}{c}{$(\boldsymbol{\%})$} \\
\hline Plantation & 385,606 & 28.7 & 568,712 & 42,1 & 13.0 \\
Agroforest & 185,906 & 13.8 & 120,662 & 8,9 & -4.8 \\
Shrubland & 146,846 & 10.9 & 126,359 & 9.37 & -1.5 \\
Forest & 551,295 & 41.0 & 415,456 & 30.9 & -10.1 \\
Dry land farming & 55,610 & 4.1 & 79,476 & 6.00 & 1.8 \\
Settlement & 1,450 & 0.1 & 8,745 & 0.7 & 0.5 \\
Sawah & 10,234 & 0.8 & 17,247 & 1.3 & 0.5 \\
Bareland & 1,005 & 0.1 & 1,161 & 0.09 & 0.0 \\
Mangrove & 150 & 0.0 & 153 & 0.01 & 0.0 \\
Water and swamps & 7,460 & 0.6 & 7,598 & 0.56 & 0.0 \\
\hline \multicolumn{1}{c}{ Total } & $1,345,562$ & 100 & $1,345,562$ \\
\hline \multicolumn{7}{c}{}
\end{tabular}

\subsection{Climate Change Scenarios}

To account for climate change impact, we calculated the changes in the climatology of future rainfall and mean surface temperature scenarios over the studied region. The future changes were calculated respective to 1981-2010 baseline periods. We used simple delta method to downscale and correct biases of the rainfall and surface temperature data obtained from the outputs of 24 CMIP5 GCMs. To simplify the downscaling process, we used a bias correction tool developed by Faqih (2017), that is specifically designed to statistically downscale the outputs of CMIP5 GCMs for developing climate scenarios in Indonesia.

The model output from CMIP5 GCMs used the recent climate change scenario called as Representative Concentration Pathways (RCP) (Moss, 2010). There are four scenarios available in the long-term climate change projections of RCP scenarios based on their possible range of radiative forcing values in 2100 , i.e. RCP2.6, RCP4.5, RCP6.0 and RCP8.5. For this study, we only used the moderate scenario of RCP4.5. The pathway of this scenario is "stabilization without overshoot", which means that it stabilizes radiative forcing at $4.5 \mathrm{Wm}^{-2}$ (equal to $650 \mathrm{ppm} \mathrm{CO} 2$-equiv) in year 2100 without exceeding that value afterwards (Thompson et al., 2011).

\subsection{SWAT Calibration and Validation}

We calibrated the model using version 2012 of the SWAT-CUP software package. The SWAT-CUP is an interface for auto-calibration that was developed for SWAT (Abbaspour, 2015). The calibration was carried out in year 2007-2009 and the validation in year 20132014. Nash-Sutcliff efficiency (NSE) and Percent Bias (PBIAS) were used to evaluate the result of the calibration and the validation. The NSE is a normalized statistic that determines the relative magnitude of the residual variance compared to the measured data variance (Nash and Sutcliffe, 1970). The PBIAS measures the average tendency of the simulated data to be larger or smaller than the observations (Gupta et al., 1999). The optimum value is zero, and low magnitude values indicate better simulations. The model input parameters that were used for the calibration process and their fitted values after calibration are shown in Table 3.

Table 3. The initial and the calibrated values of SWAT input parameters

\begin{tabular}{|c|c|c|c|}
\hline Parameters & Descriptions & $\begin{array}{l}\text { Initial } \\
\text { value }\end{array}$ & $\begin{array}{l}\text { Best fit } \\
\text { values }\end{array}$ \\
\hline ALPHA_BF & $\begin{array}{l}\text { Baseflow recession } \\
\text { constant }\end{array}$ & $0.0-1.0$ & 0.91 \\
\hline SOL_AWC & $\begin{array}{l}\text { Available water } \\
\text { capacity of the soil } \\
\left(\mathrm{mm} \mathrm{H}_{2} \mathrm{O} / \mathrm{mm} \text { soil }\right)\end{array}$ & $-0.2-0.4$ & $0.04(\mathrm{~V})^{\mathrm{a}}$ \\
\hline OV_N & $\begin{array}{l}\text { Manning's "n" value } \\
\text { for overland flow }\end{array}$ & $-0.2-1.0$ & $0.29(\mathrm{~V})^{\mathrm{a}}$ \\
\hline GW_DELAY & $\begin{array}{l}\text { Groundwater delay } \\
\text { time (days) }\end{array}$ & $30-450$ & 57.2 \\
\hline $\mathrm{CN} 2$ & Curve Number & $-0.2-0.9$ & $0.006(\mathrm{~V})^{\mathrm{a}}$ \\
\hline GWQMN & $\begin{array}{l}\text { Water depth in a } \\
\text { shallow aquifer for a } \\
\text { return flow (mm } \\
\mathrm{H} 2 \mathrm{O} \text { ) }\end{array}$ & $0.0-2.0$ & 0.45 \\
\hline GW_REVAP & $\begin{array}{l}\text { Evaporation from the } \\
\text { ground water }(\mathrm{mm})\end{array}$ & $0.0-0.2$ & 0.07 \\
\hline CH_N2 & $\begin{array}{l}\text { Manning's "n" value } \\
\text { for the main channel }\end{array}$ & $0.0-0.3$ & 0.15 \\
\hline CH_K2 & $\begin{array}{l}\text { Eff. hydraulic } \\
\text { conductivity in the } \\
\text { main channel } \\
\text { alluvium }(\mathrm{mm} / \mathrm{hr})\end{array}$ & $5.0-130$ & 24.4 \\
\hline SOL_K & $\begin{array}{l}\text { Saturated hydraulic } \\
\text { conductivity }\left(\mathrm{mm} \mathrm{h}^{-1}\right)\end{array}$ & $-0.8-0.8$ & $0.12(\mathrm{~V})^{\mathrm{a}}$ \\
\hline
\end{tabular}

${ }^{\mathrm{a}}(\mathrm{V})$ = Variable fraction depending on land-use and soil, changes in calibration were therefore expressed as fraction 


\section{Result and Discussion}

\subsection{SWAT Model Performance}

The SWAT model performed well (Fig. 2) with the NSE values of 0.80-0.85 (calibration) and 0.84-0.86 (validation) and the PBIAS values ranges between -3 and 1.3 (calibration) and between 7.0 and 11.9 (validation).

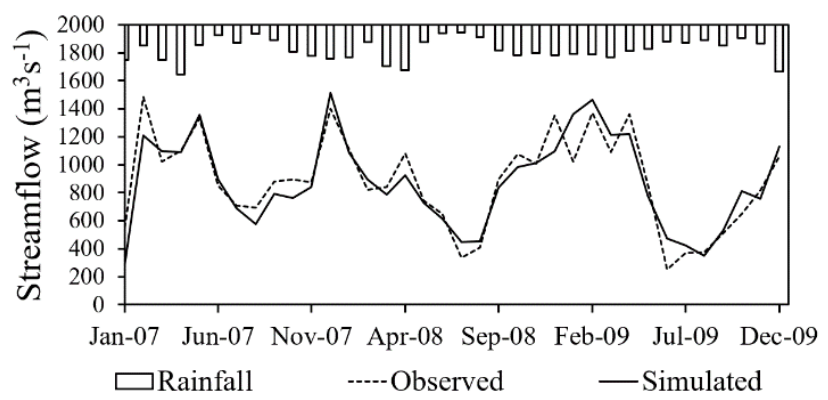

Figure 2. Observed and simulated discharge of MT watershed
After calibration and validation, the model was used to simulate relative impact of the land use change and climate change on the stream flow fluctuation. We simulated 3 scenarios for future condition (2025): a) impact of land use change, b) impact of climate change and, c) coupled impact of climate change and land use change.

\subsection{Impact of Land Use Change on The Stream Flow Fluctuation}

In this scenario, the climate input parameter (rainfall and temperature) of the SWAT model was based on the baseline year (2010). Meanwhile, the soil and crop input parameter of the model was based on the year 2025 land use map (Table 2). The land use change led to $40 \%$ decrease of the minimum discharge in the dry season and $65 \%$ increase of the maximum peak discharge in wet season compared to those of baseline (Fig. 3; Table 4). The increased streamflow fluctuation was mainly caused by factors related to the soil degradation such as lower soil infiltration, higher bulk density, and increased CN (Curve Number) values. The low infiltration rate increases surface runoff component and in turn it increases the peak discharge during wet season and reduced the minimum discharge during consecutive dry season.

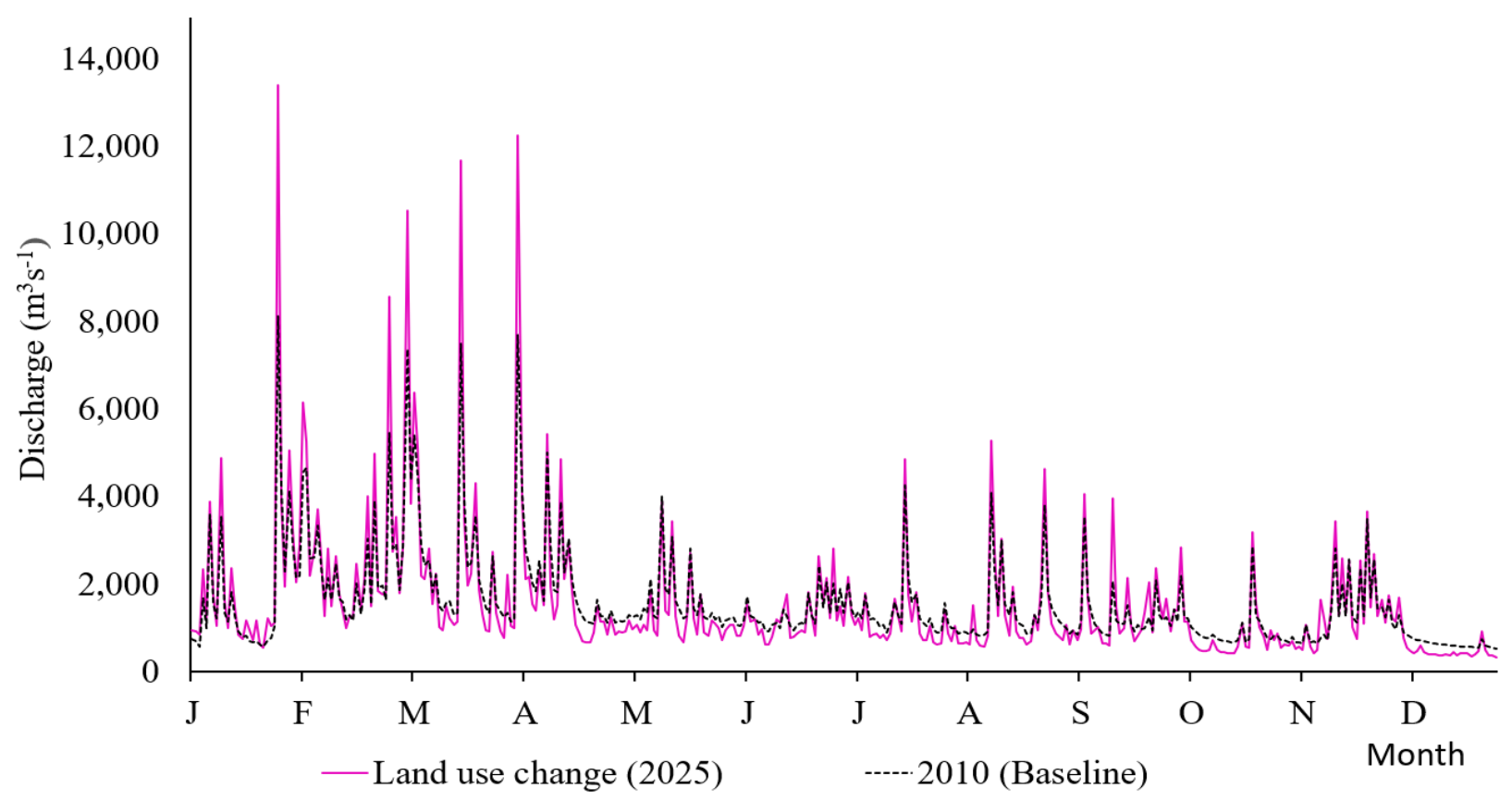

Figure 3. Impact of the land use change on the discharge fluctuation

\subsection{Impact of The Climate Change on The Stream Flow Fluctuation}

In this scenario, we adjusted the climate input parameter (rainfall and temperature) to reflect climate change in 2025 but kept the soil and crop parameters unchanged based on the baseline land-use map.
The future rainfall calculated from the downscaled rainfall of 24 CMIP5 GCM outputs showed both negative as well as positive variability respectively to the baseline value in 1981-2010 periods (Fig. 4). To adapt Fig. 4 for the rainfall input of the SWAT model, we also considered other related studies. According to the Naylor et al. (2007), seasonal pattern of rainfall in Indonesia has changed with up to $75 \%$ decrease in rainfall in the dry season (July-September). 


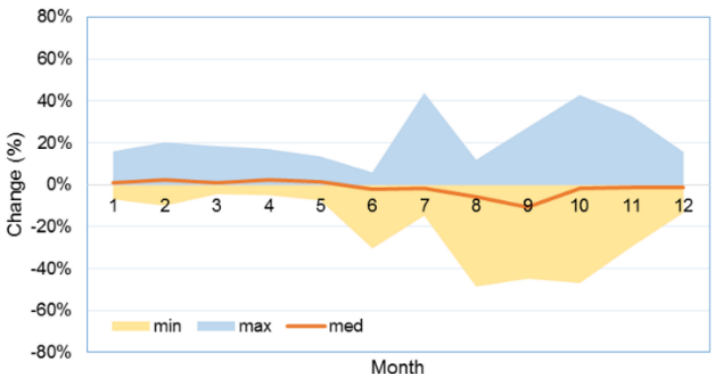

Figure 4. Uncertainties in the change of future rainfall in the Merangin Tembesi Watershed (2025)

Meanwhile, Hulme and Sheard (1999), predicted that during the wet season (December-February), parts of Sumatra and Kalimantan become 10 to 30 percent wetter by the 2080's. Into a certain extend, both these studies are in line with our climate change prediction. Considering our rainfall prediction using 24 CMIP5 GCM outputs and both studies, we adapt the rainfall input of the SWAT model by increasing baseline daily data by $20 \%$ during December-February (Hulme and Sheard, 1999) and reducing them by $10 \%$ during JulySeptember according to the median value shown by red line in Fig. 4.
For the temperature input, we used the median value (red line) of the downscaled outputs of 24 CMIP5 GCMs (Fig. 5). Median value of the temperature scenarios in $2025 \mathrm{~s}$ is around $0.6{ }^{\circ} \mathrm{C}$ with the highest value projected by the model reaches $1.1^{\circ} \mathrm{C}$.

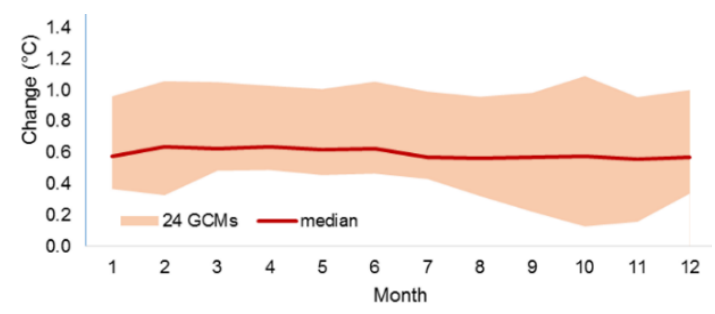

Figure 5. Uncertainties in the change of future surface temperature under RCP4.5 scenario in the Merangin Tembesi Watershed (2025s)

The predicted climate change showed $96 \%$ increase of the maximum peak discharge during rainy season and $32 \%$ decrease of the minimum discahrge during dry season compared to those of baseline (Fig. 6; Table 4).

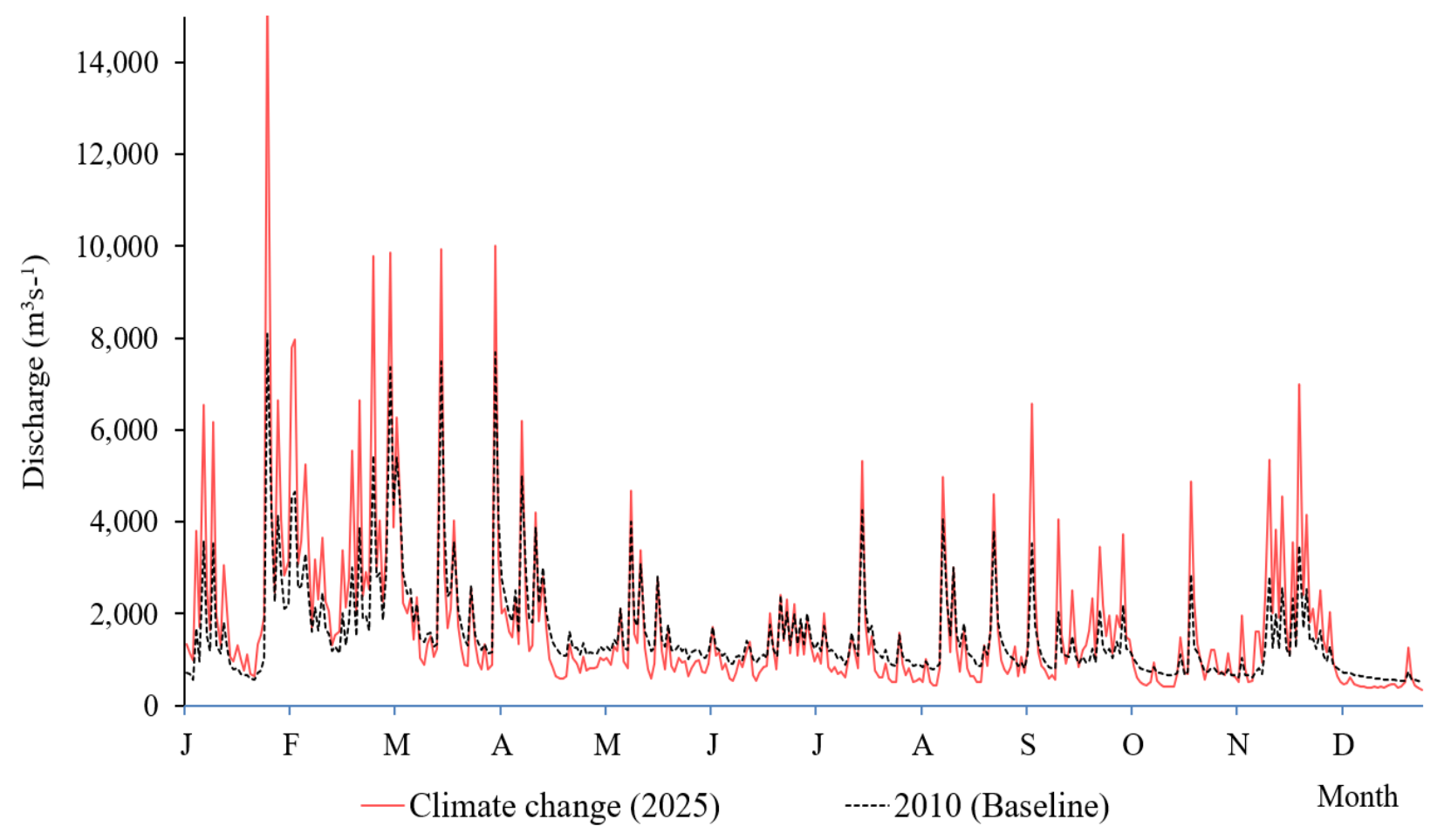

Figure 6. Impact of the climate change on the streamflow fluctuation

Tabel 4. Relative impact of change in climate and land use on the streamflow fluctuation

\begin{tabular}{lccccccc}
\hline \multirow{2}{*}{$\begin{array}{l}\text { Streamflow char- } \\
\text { acteristics }\end{array}$} & Baseline & \multicolumn{2}{c}{ Land use change } & \multicolumn{2}{c}{ Climate change } & \multicolumn{2}{c}{ Coupled change } \\
& $\mathbf{m}^{\mathbf{3}} \mathbf{s}^{-\mathbf{1}}$ & $\mathbf{m}^{\mathbf{3}} \mathbf{s}^{-\mathbf{1}}$ & Change $(\boldsymbol{\%})$ & $\mathbf{m}^{\mathbf{3}} \mathbf{s}^{-\mathbf{1}}$ & Change (\%) & $\mathbf{m}^{\mathbf{3}} \mathbf{s}^{-\mathbf{1}}$ & Change (\%) \\
\hline Min discharge & 523 & 313 & -40 & 355 & -32 & 270 & -48 \\
Max discharge & 8,100 & 13,400 & +65 & 15,880 & +96 & 17,530 & +116 \\
Mean & 1,556 & 1,554 & 0 & 1,738 & +12 & 1,851 & +20 \\
\hline
\end{tabular}




\subsection{Coupled Land-use and Climate Changes}

In this scenario we adjusted both climate and crop input parameter of the SWAT model simultaneously considering the climate change and the land use change in the previous sections. The coupled change in climate and land use sharply decreased the minimum discharge (48\%) and increased the maximum peak discharge (116\%, Table 4)).

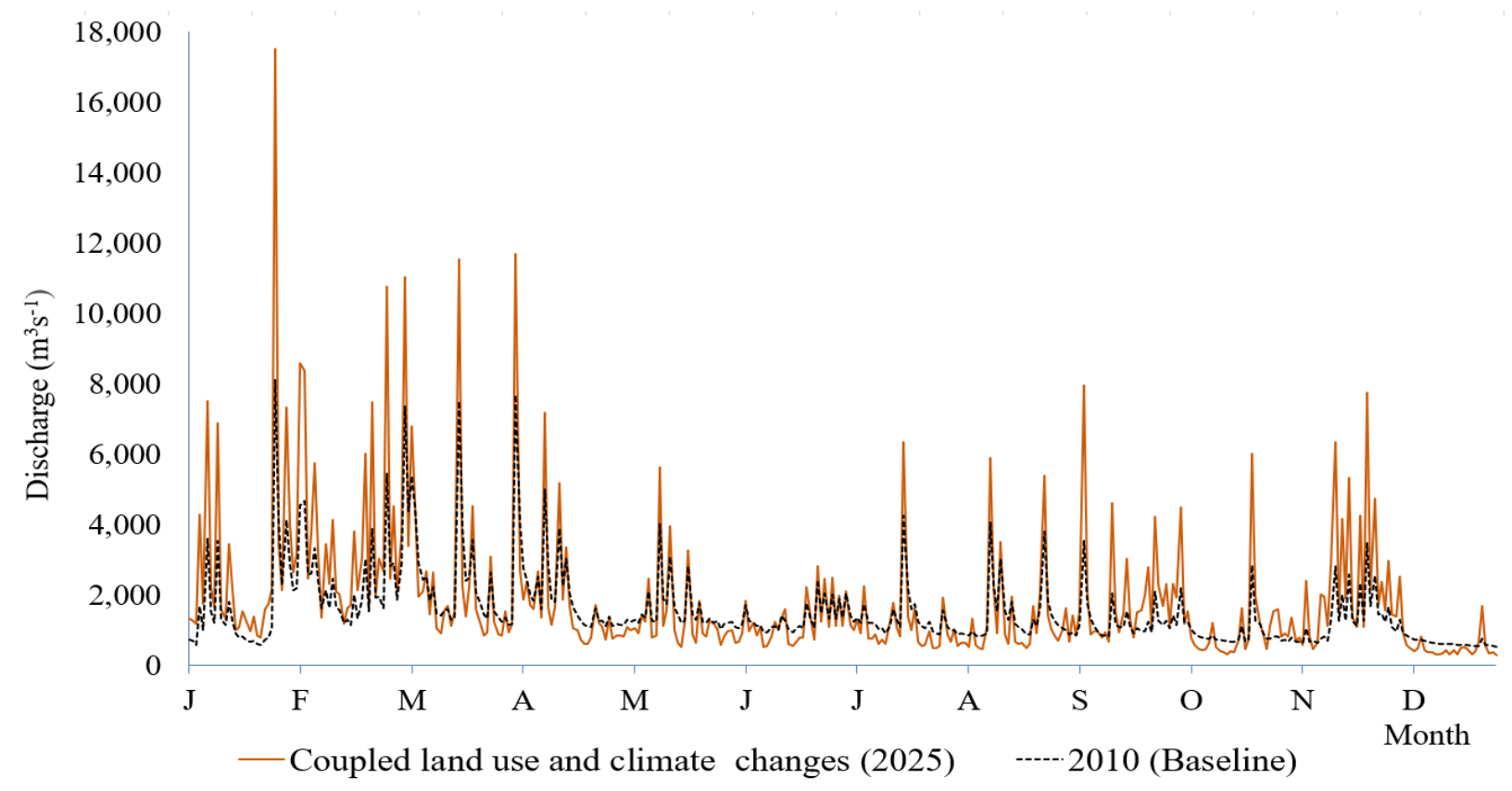

Figure 7. Impact of the coupled land-use and climate changes streamflow fluctuation

\subsection{Relative Impact of Change in Climate and Land Use on The Stream Flow}

Both changes indicated significant impact on the extreme events such as maximum peak discharge and minimum discharge. The impact of the climate change on the increased peak discharge is more significant compared to that of land use change. Meanwhile, the impact of the land use change on the decreased minimum discharge is more significant compared to that of the climate change. Knowing relative contribution of the land use and the climate change on the future discharge fluctuation enables government and communities to select appropriate combination of mitigation and adaptation measure in Indonesia. As an example, to mitigate the decreased minimum discharge because of land use change, proper land use management such as sufficient proportion of protection forest areas in a river basin should be maintained. Forest land use has been identified by many researchers as the most effective land use in increasing water flow regulation of a watershed (Bruijnzeel, 1989; 2004). In addition to sufficient forest area in a watershed, effective soil and water conservation measures should be introduced in the agricultural area in a watershed (Tarigan et al., 2016b). The soil and water conservation measures increase water infiltration and reduces sediment flowing to the downstream reservoir. Both measures greatly enhance water security in the future. On the other hand, increased peak discharge because of the climate change is often better to adapt rather than to mitigate.

\subsection{Comparison with Similar Studies in Other Regions}

Several other studies have reported the impact of changes in climate and land use. Most of these studies were carried out in China (arid-semi arid regions). Seven out of eleven reviewed studies showed that climate change have stronger impact on the streamflow than that of land use change (Table 5). Meanwhile, four reviewed studies showed that land use change have stronger impact. A study in Kenya showed that land use change had stronger impact than that of climate change. Relative impact of change in climate and land use are dependent on the type of climate zone and type of land use change. Deforestation and afforestation seem to be the type of land use change that affect streamflow more frequently. A watershed situated in arid-semi arid regions tends to be more sensitive to forest cover change. Deforestation or afforestation in drier regions (mean annual precipitation $<1000 \mathrm{~mm}$ ) was found to have greater impact on runoff than in wetter regions (Jackson et al., 2005). 


\begin{tabular}{|c|c|c|c|c|c|}
\hline \multirow[b]{2}{*}{ Authors } & \multirow[b]{2}{*}{ Location } & \multirow[b]{2}{*}{ Methods } & \multicolumn{2}{|c|}{ Impact of changes in } & \multirow[b]{2}{*}{$\begin{array}{c}\text { Human activi- } \\
\text { ties }\end{array}$} \\
\hline & & & Climate & $\begin{array}{c}\text { Human activity/ Land } \\
\text { use change }\end{array}$ & \\
\hline Ma et al., 2008 & $\begin{array}{l}\text { Northwest } \\
\text { China }\end{array}$ & $\begin{array}{l}\text { Trend analy- } \\
\text { sis }\end{array}$ & $\begin{array}{l}64 \% \text { decrease in } \\
\text { streamflow }\end{array}$ & Limited & \\
\hline Bao et al., 2012 & $\begin{array}{l}\text { Northern } \\
\text { China }\end{array}$ & $\begin{array}{l}\text { Mann-Ken- } \\
\text { dall test }\end{array}$ & $\begin{array}{l}26-59 \% \text { decrease in } \\
\text { streamflow }\end{array}$ & $\begin{array}{l}42-74 \% \text { decrease in } \\
\text { streamflow }\end{array}$ & Afforestation \\
\hline Khoi et al., 2014 & $\begin{array}{l}\text { Be River, } \\
\text { Vietnam }\end{array}$ & $\begin{array}{l}\text { SWAT } \\
\text { model }\end{array}$ & $\begin{array}{l}26.3 \% \text { increase in } \\
\text { annual streamflow }\end{array}$ & $\begin{array}{l}1.2 \% \text { increase in annual } \\
\text { streamflow }\end{array}$ & Deforestation \\
\hline Li et al., 2014 & $\begin{array}{l}\text { Northeast } \\
\text { China }\end{array}$ & $\begin{array}{l}\text { Mann- } \\
\text { Kendall test }\end{array}$ & - & $\begin{array}{l}70 \% \text { decrease in stream- } \\
\text { flow }\end{array}$ & Deforestation \\
\hline Li et al., 2009 & $\begin{array}{l}\text { Loess Plat- } \\
\text { eau of } \\
\text { China }\end{array}$ & $\begin{array}{l}\text { SWAT } \\
\text { model }\end{array}$ & $\begin{array}{l}95.8 \% \text { decrease in } \\
\text { streamflow }\end{array}$ & $\begin{array}{l}9.6 \% \text { decrease in } \\
\text { streamflow }\end{array}$ & $\begin{array}{l}\text { Expansion of } \\
\text { grassland }\end{array}$ \\
\hline Guo et al., 2016 & $\begin{array}{l}\text { North west- } \\
\text { ern China }\end{array}$ & $\begin{array}{l}\text { SWAT } \\
\text { model }\end{array}$ & $\begin{array}{l}102.8 \% \text { increase in } \\
\text { annual streamflow }\end{array}$ & $\begin{array}{l}2.8 \% \text { decrease in } \\
\text { streamflow }\end{array}$ & \\
\hline Mwangi et al., 2016 & Kenya & $\begin{array}{l}\text { Mann- } \\
\text { Kendall tests }\end{array}$ & $\begin{array}{l}2.5 \% \text { increase in } \\
\text { annual streamflow }\end{array}$ & $\begin{array}{l}97.5 \% \text { increase in annual } \\
\text { streamflow }\end{array}$ & Deforestation \\
\hline He et al., 2013 & South China & & $\begin{array}{l}45 \% \text { decrease in } \\
\text { streamflow }\end{array}$ & $\begin{array}{l}24 \% \text { increase in } \\
\text { streamflow }\end{array}$ & Deforestation \\
\hline Yang et al., 2017 & $\begin{array}{l}\text { Northwest } \\
\text { China }\end{array}$ & $\begin{array}{l}\text { Hydrological } \\
\text { modeling }\end{array}$ & $\begin{array}{l}107 \% \text { increase in } \\
\text { streamflow }\end{array}$ & $\begin{array}{l}7.3 \% \text { decrease in stream- } \\
\text { flow }\end{array}$ & \\
\hline Xu et al., 2014 & $\begin{array}{l}\text { Northwest } \\
\text { China }\end{array}$ & & $\begin{array}{l}26.9 \% \text { decrease in } \\
\text { streamflow }\end{array}$ & $\begin{array}{l}73.1 \% \text { decrease in } \\
\text { streamflow }\end{array}$ & Deforestation \\
\hline Zhang et al., 2016 & $\begin{array}{l}\text { Northwest } \\
\text { China }\end{array}$ & $\begin{array}{l}\text { SWAT } \\
\text { model }\end{array}$ & $\begin{array}{l}\text { Strong increase in } \\
\text { streamflow }\end{array}$ & $\begin{array}{l}\text { slight reductions in } \\
\text { streamflow }\end{array}$ & $\begin{array}{l}\text { Expansion of } \\
\text { grassland }\end{array}$ \\
\hline Zheng et al., 2009 & $\begin{array}{l}\text { Yellow } \\
\text { River Basin }\end{array}$ & & $\begin{array}{l}30 \% \text { decrease in } \\
\text { streamflow }\end{array}$ & $\begin{array}{l}70 \% \text { decrease in stream- } \\
\text { flow }\end{array}$ & \\
\hline Zhang et al., 2008 & $\begin{array}{l}\text { Loess Plat- } \\
\text { eau, China }\end{array}$ & $\begin{array}{l}\text { Mann- } \\
\text { Kendall test }\end{array}$ & - & $\begin{array}{l}50 \% \text { reduction of annual } \\
\text { streamflow }\end{array}$ & \\
\hline
\end{tabular}

\section{Conclusion}

We simulated future rainfall and temperature scenarios using the downscaled rainfall and mean surface temperature of 24 CMIP5 GCM outputs with moderate scenario of RCP4.5. For the 2025, the most considerable rainfall decrease is found in dry season, reaching almost 50\% in August. Meanwhile, the median value of the temperature scenarios in 2025 is around $0.6^{\circ} \mathrm{C}$ with the highest value projected by the model reaches $1.1^{\circ} \mathrm{C}$. We used distributed hydrologic model (SWAT) to simulate simultaneous impact of future changes in climate and land use change on the streamflow fluctuation. The SWAT model performed well with the Nash-Sutcliff efficiency values of $0.80-0.85$, (calibration) and 0.84 0.86 , (validation); and the PBIAS values ranges between -3 and 1.3 (calibration) and between 7.0 and 11.9 (validation). The coupled climate change and land use change decreased the minimum discharge $48 \%$ and increased the maximum peak discharge $116 \%$ respectively. Separately, the land use change led to $40 \%$ decrease of the minimum discharge in dry season and $65 \%$ increase of the maximum peak discharge in wet season. Meanwhile, the climate change caused $32 \%$ decrease of the minimum discharge and $96 \%$ increase of the maximum peak discharge. Both changes indicated significant impact on the extreme events such as maximum peak discharge and minimum discharge. The impact of the climate change on the increased maximum peak discharge is more significant compared to that of land use change. Meanwhile, the impact of the land use change on the decrease of the minimum discharge is more significant compared to that of the climate change. The results of this study pointed out that the climate change and the land use change potentially become important drivers to the future discharge fluctuation Indonesia. The implementation of mitigation actions such as soil and water conservation in agriculture plantation to reduce the decrease of the minimum discharge during dry season and the adaptation measures for increased the maximum peak discharge during wet season are necessary.

\section{Acknowledgments}

This study was funded by the Directorate General of Higher Education (DIKTI), Indonesia

\section{References}

Abbaspour, K. C., 2015. SWAT-CUP 2012: SWAT Calibration and Uncertainty Programs - A User Manual, 2012. Federal Institute of Aquatic Science and Technology, Eawag - Swiss.

Adnan, N. A., P. M. Atkinson, 2011. Exploring the impact of climate and land-use changes on streamflow trends in a monsoon catchment. International Journal of Climatology 31, pp. 815-831.

Afriyanti, D., C. Kroeze, A. Saad, 2016. Indonesia palm oil production without deforestation and peat conversionby 2050. Science of the Total Environment 557-558 (2016), pp. 562-570.

Arnold, J. G., D. N. Moriasi, P. W. Gassman, K. C. Abbaspour, M. J. White, R. Srinivasan, R. C. Santhi, R. D. Harmel, A. Van Griensven, M. W. Van Liew, N. Kannan, M. K. Jha, 2012. SWAT: Model use, calibration, and validation. Transac of the ASABE 55 (4), pp. 1491-1508. 
Babel, M. S., B. Shrestha, S. R. Perret, 2011. Hydrological impact of biofuel production: A case study of the khlong phlo watershed in Thailand. Agricultural Water Management 101 (1), pp. 8-26.

Babel, M. S., A. Agarwal, V. R. Shinde, 2014. Climate Change Impacts On Water Resources And Selected Water Use Sectors. In Shrestha S, M.S. Babel, Pandey (Eds.), Climate Change and Water Resources, V.P. CRC Press.

Banabas, M., M. A. Turner, D. R. Scotter, P. N. Nelson, 2008. Losses of nitrogen fertilizer under oil palm in Papua New Guinea: 1. water balance, and nitrogen in soil solution and run off. Aust. J. Soil Res 46, pp. 332-339.

Bao, Z., J. Zhang, G. Wang, G. Fu, R. He, X. Yan, J. Jin, Y. Liu, A Zhang, 2012. Attribution for decreasing streamflow of the haihe river basin, Northern China: Climate variability or human activities? Journal of Hydrology 460-461 (2012), pp. 117-129.

Boer, R., A. Faqih, 2004. An Integrated Assessment of Climate change Impacts, Adaptation and Vulnerability in Watershed Areas and Communities in Southeast Asia, Report from AIACC Project No. AS21 (Annex C, 95-126) International START Secretariat, District of Columbia, Washington.

Bruijnzeel, L. A., 1989. Deforestation and dry season flow in the tropics: a closer look. In: J of Tropical Forest Science 1 (3), pp. 229-243.

Bruijnzeel, L. A., 2004. Hydrological functions of tropical forests: not seeing the soil for the trees? Agriculture. Ecosystems and Environment 104(1), pp. 185-228.

Comte, I., F. Colin, J. K. Whalen, O. Gruenberger, J. P. Caliman, 2012. Agricultural practices in oil palm plantations and their impact on hydrological changes, nutrient fluxes and water quality in Indonesia: a review. Advances in Agronomy 116, pp. 71-124.

Drescher, J., K. Rembold, K. Allen, P. Beckschäfer, D. Buchori, Y. Clough, H. Faust, A. M. Fauzi, D. Gunawan, D. Hertel, B. Irawan, I. N. S. Jaya, B. Klarner, C. Kleinn, A. Knohl, M. M. Kotowska, V. Krashevska, V. Krishna, C. Leuschner, W. Lorenz, A. Meijide, D. Melati, M. Nomura, C. Pérez-Cruzado, M. Qaim, I. Z. Siregar, S. Steinebach, A. Tjoa, T. Tscharntke, B. Wick, K. Wiegand, H. Kreft, S. Scheu. 2016. Ecological and socioeconomic functions across tropical land-use systems after rainforest conversion. Phil. Trans. R. Soc., B 371, 20150275.

Ditjenbun, 2015. Indonesian plantation statistics. Directorate General for Plantations, Ministry of Agriculture, Indonesia.

Faqih, A., 2017. A statistical bias correction tool for generating climate change scenarios in Indonesia based on CMIP5 datasets. IOP Conference Series: Earth and Environmental Science 2017 58 (1), 012051

Guo, J., X. Su, V. P. Singh, J. Jin, 2016. Impacts of climate and land use/cover change on stream flow using SWAT and a separation method for the Xiying River Basin in Northwestern China. Water 2016, 8, 192; doi: 10.3390/w8050192.

Gupta, H. V., S. Sorooshian, P. O. Yapo, 1999. Status of automatic calibration for hydrologic models: Comparison with multilevel expert calibration. J. Hydrologic Eng. 4 (2), pp. 135-143.

Hardanto, A. Röll, Hendrayanto, D. Hölscher, 2017. Tree soil water uptake and transpiration in mono-cultural and jungle rubber stands of Sumatra. Forest Ecology and Management 397, pp. 6777.

He, Y., K. Lin, X. Chen, 2013. Effect of land use and climate change on run off in the dongjiang basin of South China. Mathematical Problems in Engineering Volume 2013 (2013). http://dx.doi.org/10.1155/2013/471429.

Hulme, M., N. Sheard, 1999. Climate Change Scenarios for Indonesia. Climatic Research Unit, Norwich, United Kingdom.

Jackson, R. B., E. G. Jobbágy, R. Avissar, S. B. Roy, D. J. Barrett, C. W. Cook, K. A. Farley, D. C. Le Maitre, B. A. Mc Carl, B. C. Murray, 2005. Trading water for carbon with biological carbon sequestration. Science 310 (5756), pp. 1944-1947.

Khoi, D. N., T. Suetsugi, 2014. Impact of climate and land-use changes on hydrological processes andsediment yield - a case study of the be river catchment, Vietnam. Hydrological Sciences Journal-Journal des Sciences Hydrologiques, 59 (5).
Klasen, S., K. M. Meyer, C. Dislich, M. Euler, H. Faust, M. Gatto, E. Hettig, D. N. Melati, I. N. S. Jaya, F. Otten, C. P. Cruzado, S. Steinbach, S. Tarigan, K. Wiegand, 2016. Economic and ecological trade-offs of agricultural spezialization at different spatial scales. Ecological Economics 122 (2016), pp. 111-120.

Li, F., G. Zhang, Y. J. Xu, 2014. Separating the impacts of climate variation and human activities on runoff in the Songhua River Basin, Northeast China. Water 2014, 6, 3320-3338; doi: 10.3390/w6113320.

Li, Z., W. Liu, X. Zhang, F. Zheng, 2009. Impacts of land use change and climate variability on hydrology in an agricultural catchment on the loess plateau of China. Journal of Hydrology 377 (2009), pp. $35-42$.

Ma, Z., S. Kang, L. Zhang, L. Tong, X. Su, 2008. Analysis of impacts of climate variability and human activity on streamflow for a river basin in arid region of northwest China. Journal of Hydrology (2008) 352, pp. 239- 249.

Mcintyre, N., 2007. How will climate change impact on fresh water security? Dept. of Civil and Environmental Engineering and Grantham Institute for Climate Change, Imperial College London, London.

Meijide, A., A. Roll, F. Fan, M. Herbst, F. Niu, F. Tiedemann, T. June, A. Rauf, D. Holscher, A. Knohl., 2017. Controls of water and energy fluxes in oil palm plantations: Environmental variables and oil palm age. Agricultural and Forest Meteorology 239 (2017), pp. 71-85.

Merten, J., A. Roll, T. Guillaume, A. Meijide, S. Tarigan, H. Agusta, C. Dislich, C. Dittrich, H. Faust, D. Gunawan, Hendrayanto, A. Knohl, Y. Kuzyakov, K. Wiegand, D. Holscher, 2016. Water scarcity and oil palm expansion: social views and environmental processes. Ecology and Society 21 (2), pp. 5-16.

Moss, R. H., 2010. The next generation of scenarios for climate change research and assessment. Nature, 2010. 463.

Mwangi, H. M., S. Julich, S. D. Pati, M. A. McDonald, K. H. Feger, 2016. Relative contribution of land use change and climate variability on discharge of upper Mara River, Kenya. Journal of Hydrology: Regional Studies 5 (2016), pp. 244-260.

Naylor, R. L., D. S. Battisti, D. J. Vimont, W. P. Falcon, M. S. Burke, 2007. Assessing risks of climate variability and climate change for Indonesian rice agriculture. Proceedings of the National Academy of Sciences of the United States of America 104 (19), pp. 7752-7757.

Nash, J., J. V. Sutcliffe, 1970. River flow forecasting through conceptual models 1: A discussion of principles, J. Hydrol 10, pp. 282-290.

Pereira, L. S., T. Oweis, A. Zairi, 2002. Irrigation management under water scarcity. Agric. Wat. Management 57 (2002), pp. 175-206.

Rijsberman, F. R., 2006. Water scarcity: Fact or fiction? Agric. Wat. Management 80 (2006), pp. 5-22.

Satriawan, H., F. Zahrul, Agusni, 2017. Soil conservation techniques in oil palm cultivation for suatainable agriculture. Jurnal Pengelolaan Sumberdaya Alam dan Lingkungan 7 (2), pp. 178-183.

Sinukaban, N., S. D. Tarigan, W. Purwakusuma, D. Baskoro, 2000 Analysis of watershed function. Sediment transfer across various types of filterstrips. Institut Pertanian Bogor, Bogor.

Tarigan, S., Sunarti, S. Widyaliza, 2015. Expansion of oil palm plantations and forest cover changes in Bungo and Merangin Districts, Jambi Province, Indonesia. Elsevier Procedia Environmental Sciences 20155 (6), pp.199-205.

Tarigan, S. D., 2016a. Land cover change and its impact on flooding frequency of batanghari watershed Jambi Province, Indonesia. Procedia Environmental Sciences 33 (2016), pp. 386-392.

Tarigan, S. D., 2016b. Modeling effectiveness of management practices for flood mitigation using GIS spatial analysis functions in Upper Cilliwung watershed. IOP Conf. Series: Earth and Environmental Science 31 (2016), pp. 1-10.

Tarigan, S. D., K. Wiegand, C. Dislich, B. Slamet, J. Heinonen, K. Meyer, 2016. Mitigation options for improving the ecosystem function of water flow regulation in awatershed with rapid expansion of oil palm plantations. Sustainability of Water Quality and Ecology 8, pp. 4-13. 
Tarigan, S. D., 2018. Land use changes and plantation crop development in selected provinces in Sumatra and Kalimantan. IOP Conf. Series: Earth and Environmental Science 149 (2018) 012013.

Wicke, B., R. Sikkema, V. Dornburg, A. Faaij, 2011. Exploring land use changes and the role of palm oil production in Indonesia and Malaysia. Land Use Policy 28 (1), pp. 193-206.

Xu, X., D. Yang, H. Yang, H. Lei, 2014. Attribution analysis based on the budyko hypothesis for detecting the dominant cause of run off decline in Haihe basin. Journal of Hydrology 510 (2014), pp. 530-540.

Yang, L., Q. Feng, Z. Yin, X. Wen, J. Si, C. Li, R. C. Deo, 2017. Identifying separate impacts of climate and land use/cover change on hydrological processes in upper stream of Heihe River, Northwest China. Hydrological Processes 31 (5), 1100 1112.

Zimmermann, B., H. Elsenbeer, 2008. Spatial and temporal variability of soil saturated hydraulic conductivity in gradients of disturbance. J. Hydrol. 361, pp. 78-95.
Zhang, X. P., L. Zhang, J. Zhao, P. Rustomji, P. Hairsine, 2008. Response of stream flow to changes in climate and land use/cover in the Loess Plateau, China. Water Resour. Res. 44, W00A07, http://dx.doi.org/10.1029/2007WR006711.

Zhang, L., Z. Nan, Y. Xu, S. Li, 2016. Hydrological impacts of land use change and climate variability in the Headwater Region of the Heihe River Basin, Northwest China. PLoS One. 201611 (6), e0158394. doi:10.1371/journal.pone.0158394.

Zheng, H., L. Zhang, R. Zhu, C. Liu, Y. Sato, Y. Fukushima, 2009. Responses of streamflow to climate and land surface change in the headwaters of the Yellow River Basin, Water Resour. Res., 45, W00A19, doi: 10.1029/2007WR006665.

Zuma, D. S, K. Murtilaksono, Y. Suhartono, 2017. Analysis of rainfall and discharge with SWAT model using the moving average method in Ciliwung Hulu Watershed. Jurnal Pengelolaan Sumberdaya Alam dan Lingkungan 7 (2), pp. 98-106. 